\title{
Digitalization as a Tool for Ensuring Innovative Development of Restaurant Business
}

\author{
TATYANA V. SHTAL ${ }^{1 *}$, TETIANA O. STAVERSKA ${ }^{2}$, VIKTORIYA YU. SVITLICHNA ${ }^{3}$, SOFIIA V. \\ KRAVTSOVA ${ }^{4}$, LYUDMYLA N. KRAYNYUK ${ }^{5}$, MARIIA M. POKOLODNA ${ }^{6}$ \\ ${ }^{1,2}$ Department of International Economics and Management of Foreign Economic Activity, SIMON KUZNETS \\ KHARKIV NATIONAL UNIVERSITY OF ECONOMICS, UKRAINE. *E-mail: t.shtal6270-3@nuos.pro \\ ${ }^{3,4,5,6}$ Department of Tourism and Hospitality, O.M. BEKETOV NATIONAL UNIVERSITY OF URBAN ECONOMY IN \\ KHARKIV, UKRAINE
}

\begin{abstract}
The aim of the study is to identify and systematize innovations in the restaurant business in the context of digitalization of business process management. The article proves that the globalization of crisis phenomena in the national and world economy, in particular complicated by the COVID19 pandemic, the variability of the market environment necessitates an innovative orientation of the restaurant business. The definition of "innovation in the restaurant business" as a creative entrepreneurial process of creating and/or improving and commercializing a new product, service or technology with the appropriate transformation of management methods, which increase the efficiency of business processes while bifurcating quality management parameters and form the basis for further development. The classification of the combination of innovations in the restaurant business according to the criteria on the basis of the results of the transformation of the combinatorial clustering of innovations is given. It is proved that digitalization creates a basis for innovative business process management formats of restaurants, which allow to form their own ecosystem of information and communication interaction with consumers and other stakeholders, based on customer orientation, innovation, partnership and synergy. Factors of gradual and rapid digitalization of the restaurant business are highlighted, the combined effect of which necessitates the introduction of adaptive models of innovative digital management by restaurant business owners.
\end{abstract}

Keywords: innovative development, business model, combination and clustering of innovations, digital transformation, management methods

JEL Classification: D 89, L30, J45 
Tatyana V. Shtal, Tetiana O. Staverska, Viktoriya Yu. Svitlichna, Sofiia V. Kravtsova, Lyudmyla N. Kraynyuk, Mariia M. Pokolodna

\section{Introduction}

The intensity of global economic development and techno-globalization is accelerating the transformation of the post-industrial economy into a digital one. The rapid development of the digital economy contributes to a significant expansion of the range of goods and services on the market, accelerates and reduces the cost of exchange processes. In addition, the digital economy leads to the formation of a new value - data, with the advent of appropriate business models and digital platforms. This trend is due to the innovative direction of development of all sectors of the economy, including the restaurant business.

Current trends in economic development necessitate innovative changes in management technologies and principles of operation of enterprises in the restaurant business. A characteristic feature of the restaurant business is customer orientation, so today companies in this field "offer not only food services, but accompany the process of food consumption with other visual and emotional factors, which necessitates the need to develop not only food services, but also to provide additional services. It requires successful management of emotions and impressions of the clients" (Shpak et al., 2016). Under such conditions, in order to obtain competitive advantages, innovations in assortment policy, marketing and information technologies, resource provision and business management technologies in general prove their effectiveness. The globalization of crisis phenomena in the national and world economy, in particular complicated by the COVID19 pandemic, fierce competition in the market necessitate innovative orientation of further development of restaurant business, in particular, in the context of digitalization of the whole spectrum of business processes.

Digital globalization, characterized by the infinity and continuity of flows of information, knowledge, ideas and innovations, is intensifying the transition of the world economy to a digital format dominated by artificial intelligence, automation and digital platforms. Penetrating into all spheres of society, the latest digital technologies allow the state, business and the population to interact more effectively and contribute to the achievement of sustainable development goals (Davydova et al., 2020). The results of the World Economic Forum research show that $84 \%$ of "Internet of Things technologies" can contribute to the achievement of the UN Global Sustainable Development Goals (Dzhun, 2019). New operating conditions necessitate the improvement of quality parameters of domestic restaurant business development, and the main tools for achieving development goals are innovative business management models based on the use of innovative solutions and digital technologies.

The current operating conditions of the restaurant business are characterized by significant turbulence in the market environment, socio-political instability in the country and the deepening financial crisis, which is complicated by quarantine restrictions related to the COVID19 pandemic.

\section{Materials and methods}

According to the platform for working with open data Opendatabot and experts of Poster, in 2019 the market of restaurant business in Ukraine was represented by more than 50,000 establishments (Fig. 1).

After two weeks of strict quarantine, $63 \%$ of restaurant establishments stopped working. In total, during the period of strict quarantine around 12 thousand institutions of this group were liquidated as economic entities (Fig. 2).

During the period of quarantine restrictions, restaurants and other catering establishments suffered significant losses, which led to a reduction in budget allocations by $23 \%$ or UAH 535.5 million. The most difficult for the restaurant business was April, after which a gradual recovery began, and in September, these companies almost reached the 2019 figures. The related business - "beverage service" (bars, taverns, snack bars, etc.) - reduced deductions by almost $30 \%$. During the most difficult periods, April-May, the state received UAH 10 million a month from bars, taverns, snack bars, pubs and cafes $-50 \%$ of the 2019 amounts (Fig. 3). 
Figure 1 Trends in the number of restaurant establishments in 2013-2019

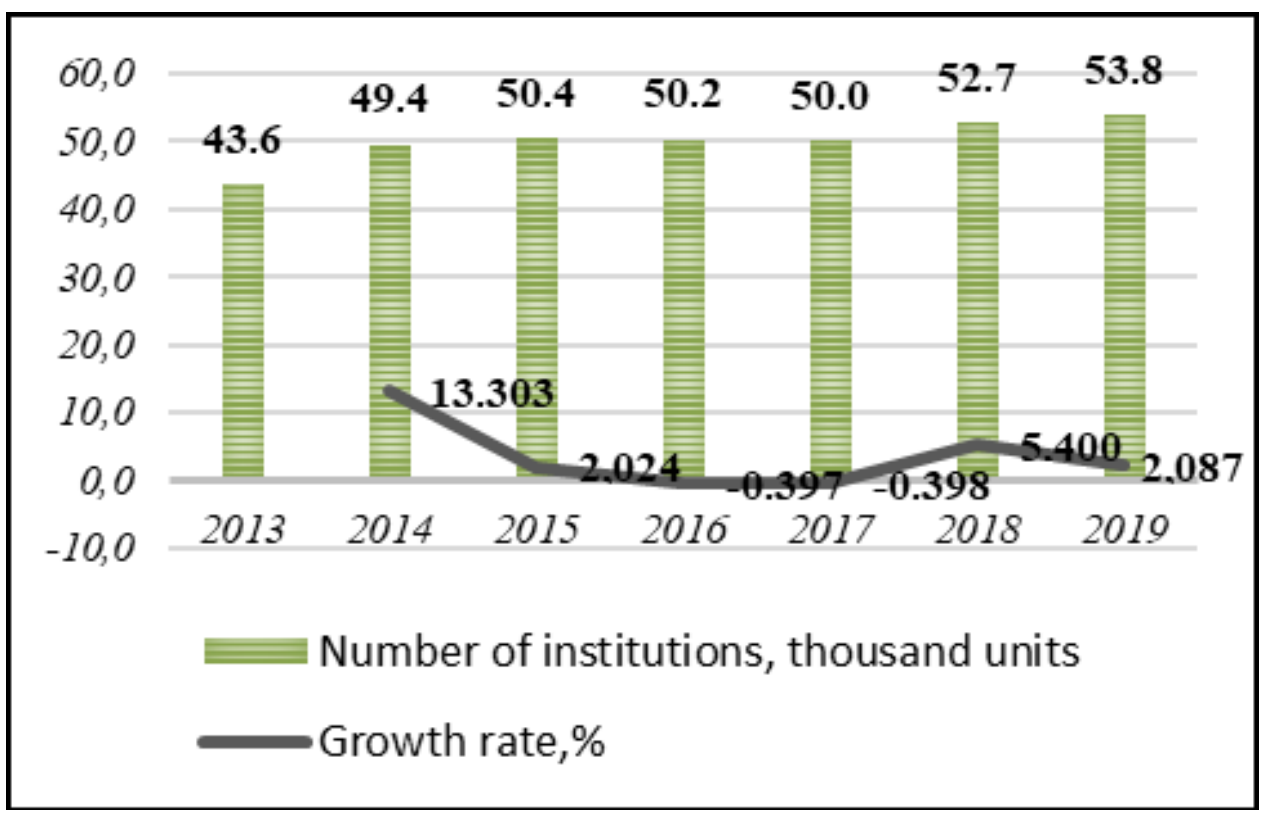

It should be emphasized that the restaurant business was able to withstand the conditions of strict quarantine mainly those who carried out targeted food delivery or worked "takeaway". Most of these institutions have already implemented or promptly implemented certain marketing and organizational innovations, the effectiveness of which has been complemented by the support of relevant digital applications and platforms. This example of operational adaptation proves the feasibility of the study of digitalization as a component tool for innovative development of the restaurant business in modern business conditions.

Given the urgency of the problems of sustainable development, sustainable competitiveness and financial stability of the restaurant business in today's complex conditions, the purpose of this study is to identify and systematize innovations in the restaurant business in the context of digitalization of business process management.

Figure 2 Dynamics of reduction of the number of restaurant establishments during the period of strict quarantine restrictions

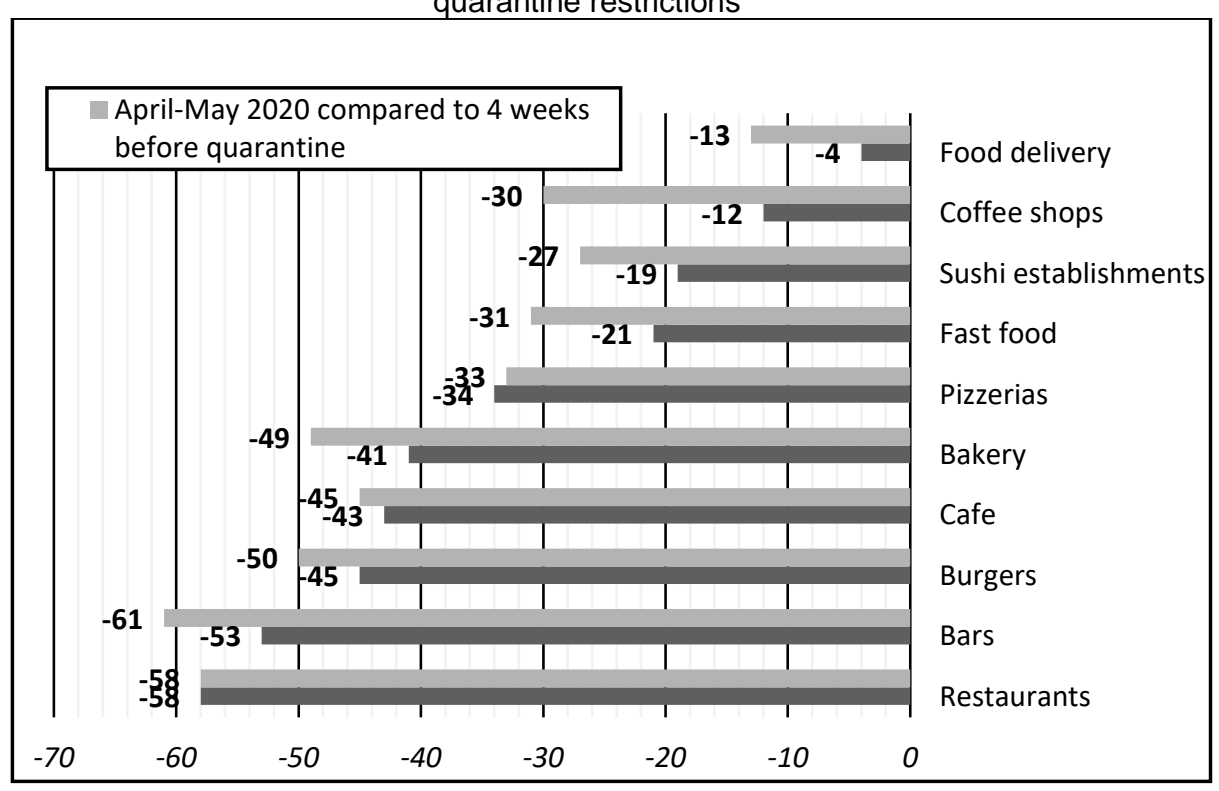


Figure 3 Volumes of payment of tax payments by restaurants, catering establishments and beverage service in March-September 2019 and 2020, UAH million

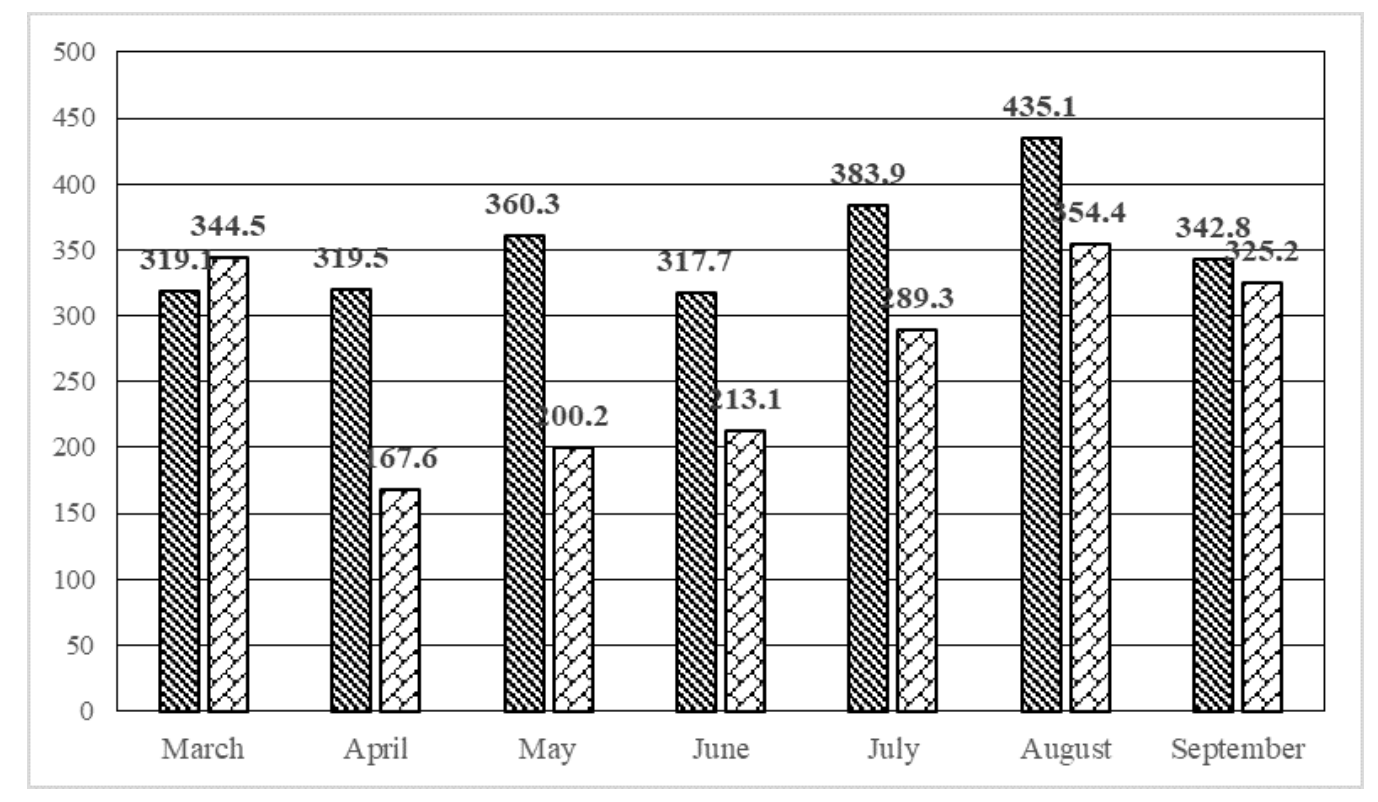

\section{Results and discussion}

The emergence of theories of innovative development began in the second half of the XIX - first half of XX century, although as early as the XVIII century Scottish economist Adam Smith in his work "Research on the nature and causes of wealth" noted the role of technological innovation in economic productivity. The founder of the classical theory of innovation in economics is the Austrian scientist Josef Alois Schumpeter, who believed that innovation is not just an innovation, but a factor of production. At the same time, the scientist was interested not so much in "specific factors of change" as in "the mechanism of change, that is, the way in which changes occur" (Schumpeter, 2011). As such a mechanism, J. Schumpeter considered the process of forming new production combinations, namely:

1) making a new good;

2) introduction of a new method of production;

3) development of a new market;

4) obtaining a new source of raw materials or semi-finished products;

5) organizational restructuring.

According to Schumpeter's theory, the determining factor in the process is the entrepreneur, thanks to whom economic development occurs through a new combination of factors of production. The scientist defined innovation as a new scientific and organizational combination of production factors motivated by entrepreneurship (Antonyuk, 2003). That is, innovation is, on the one hand, the end result of the creative process, which is embodied in the form of a new product, technology, method, etc., and on the other - the process of obtaining this result, introduction of new technologies, methods or improvement of old ones. The basis of successful innovation development is the creation of innovation clusters - a package of basic innovations that are implemented simultaneously.

Thus, innovation in the restaurant business is understood to mean a creative entrepreneurial process of creating and/or improving and commercializing a new product, service or technology with the appropriate transformation of management methods that increase the efficiency of business processes while bifurcating quality management parameters and form the basis for further development in general.

Modern restaurant businesses have the opportunity to implement innovative technologies in every business process. Innovations in the restaurant industry, on the one hand, can be described as production (food production), and on the other - non-production (provision of catering services and 
non-related services) (Zavgorodnya \& Tkach, 2016). At the same time, all types of innovations in the restaurant business provide certain advantages to both producers of products and services and consumers.

Modern economic conditions have led to a certain transformation of the combinatorial clustering of innovations. In our opinion, in the restaurant business combinations of innovations can be classified according to the following criteria: marketing; product (assortment); economic; social; organizational; managerial; resource; technological; information technologies (digital) (Table 1).

Table 1 Methods for ensuring flexibility and adaptability of the quality management system of business processes

\begin{tabular}{|c|c|c|}
\hline Types & Names & Summary \\
\hline \multirow[t]{3}{*}{ Economic } & $\begin{array}{l}\text { Indicators of economic assessment of quality } \\
\text { management methods }\end{array}$ & $\begin{array}{c}\text { Comparison of individual quality management } \\
\text { methods for the appropriateness of their } \\
\text { application }\end{array}$ \\
\hline & $\begin{array}{c}\text { Comprehensive assessment of alternative } \\
\text { solutions developed in groups (circles) on } \\
\text { quality problems }\end{array}$ & $\begin{array}{c}\text { Determination of the appropriateness of methods } \\
\text { when working in groups to solve quality problems } \\
\text { and apply the valuable experience of specialists in } \\
\text { teams }\end{array}$ \\
\hline & $\begin{array}{l}\text { Structuring business processes and } \\
\text { determination of their importance for the } \\
\text { results of the quality management system }\end{array}$ & $\begin{array}{l}\text { Paying attention to those links of the quality circle } \\
\text { that develop the greatest value of the product and } \\
\text { are important for quality }\end{array}$ \\
\hline \multirow[t]{2}{*}{$\begin{array}{c}\text { Socio- } \\
\text { psychological }\end{array}$} & $\begin{array}{c}\text { Development and application of the cognitive } \\
\text { abilities of workers }\end{array}$ & $\begin{array}{c}\text { Continuous training and improvement of skills of } \\
\text { employees, transfer of experience }\end{array}$ \\
\hline & $\begin{array}{l}\text { Participation in competitions and awards for } \\
\text { quality (enterprise benchmarking) }\end{array}$ & $\begin{array}{l}\text { Additional motivation in order to present the best } \\
\text { experience in the field of quality }\end{array}$ \\
\hline \multirow[t]{3}{*}{ Technological } & $\begin{array}{l}\text { Introduction of information about weak design } \\
\text { and technological aspects into technological } \\
\text { and design documentation }\end{array}$ & $\begin{array}{l}\text { Step-by-step derivation of a possible list of errors } \\
\text { for making changes in product quality indicators in } \\
\text { logical aspects }\end{array}$ \\
\hline & $\begin{array}{l}\text { Certification of the enterprise quality } \\
\text { management system according to several } \\
\text { international or national standards }\end{array}$ & $\begin{array}{l}\text { Consideration of the strengths of individual } \\
\text { standards, adaptation of the quality system to the } \\
\text { requirements of various customers }\end{array}$ \\
\hline & $\begin{array}{l}\text { Consideration of the phases of the } \\
\text { development of flexibility and adaptability of } \\
\text { the quality management system }\end{array}$ & $\begin{array}{c}\text { Identification of a stage in the development cycle } \\
\text { of the quality system and introduction of } \\
\text { appropriate mechanisms for flexibility and } \\
\text { adaptability }\end{array}$ \\
\hline \multirow[t]{3}{*}{ Administrative } & $\begin{array}{c}\text { Quality management and quality assurance } \\
\text { maps }\end{array}$ & $\begin{array}{l}\text { Matching models of probable errors and ways to } \\
\text { correct them }\end{array}$ \\
\hline & $\begin{array}{c}\text { Creation and maintenance of a group on } \\
\text { quality problems }\end{array}$ & $\begin{array}{l}\text { Implementation of the practice of teams to solve } \\
\text { quality problems and grant them legal authority in } \\
\text { the enterprise management system }\end{array}$ \\
\hline & $\begin{array}{l}\text { Involvement of employees in the development } \\
\text { of recommendations and proposals for quality }\end{array}$ & $\begin{array}{c}\text { Organisation and motivation of employees to find } \\
\text { ways to improve quality }\end{array}$ \\
\hline
\end{tabular}

The information in the maps helps to overcome deviations quickly and efficiently during business processes. The place and role of maps of quality management methods of business processes of enterprises in the mechanisms for ensuring flexibility and adaptability of the quality management system is determined by the functions of these systems and their objects (components of mechanisms). The quality development mechanism cannot consist exclusively in such a simple structural redistribution of the characteristics of products and services. In this case, product quality would not develop intensively and progressively. Some characteristics would benefit from others in the eyes of consumers. Based on the generalisation of theory and practice, the approaches to the identification of signs of flexibility of the quality management system at an enterprise and its adaptability were improved. Based on the generalisation of theory and practice on the issues of business process management, approaches to identifying signs of flexibility of the quality management system of business processes were improved. It is for the purpose of ensuring and increasing flexibility in accordance with the developed sequence that business processes need to be adapted to new management methods (for this they must be adaptable to transformations). The presented sequences and relationships allow to reasonably form the requirements for the flexibility and adaptability of the 
quality management system of business processes. It is these features that determine the attention of the system to the existing and potential management tools that are most appropriate for use in certain situations. The results of the study, which constitute and determine its scientific novelty, with explanations of their practical content for quality management systems and their flexibility and adaptability are presented in Table 2.

Table 2 Instruments for influencing the development of flexibility and adaptability of the quality management system of business processes of an enterprise

\begin{tabular}{|c|c|c|}
\hline Development names & Research methods & Practical value \\
\hline $\begin{array}{l}\text { An integrated approach to } \\
\text { decision-making in headquarters } \\
\text { units for quality management at } \\
\text { enterprises (groups, quality } \\
\text { circles), which is based on the } \\
\text { application of game theory }\end{array}$ & $\begin{array}{l}\text { Consideration of the characteristics } \\
\text { typical for the quality sphere of } \\
\text { situations that arise in case of } \\
\text { inconsistencies in the operation of } \\
\text { quality management systems, as } \\
\text { factors during modelling the } \\
\text { interaction between group members } \\
\text { (games) to assess alternatives and } \\
\text { select the optimal management } \\
\text { decision in terms of quality }\end{array}$ & $\begin{array}{l}\text { The result of game modelling can be } \\
\text { either consideration of the selected } \\
\text { optimal solution for adapting or ensured } \\
\text { flexibility of the quality management } \\
\text { system or identification of subjective } \\
\text { factors in the work of the group in terms } \\
\text { of quality, which did not allow making an } \\
\text { objective decision }\end{array}$ \\
\hline $\begin{array}{c}\text { An analytical model of } \\
\text { consideration of the links of } \\
\text { individual sections in } \\
\text { international quality } \\
\text { management standards in the } \\
\text { context of supporting the } \\
\text { adaptability and flexibility of } \\
\text { quality management systems at } \\
\text { enterprises }\end{array}$ & $\begin{array}{l}\text { It is based on the developed model of } \\
\text { modern requirements for quality } \\
\text { management systems from } \\
\text { international standards, considers the } \\
\text { new components of this philosophy, } \\
\text { which assumes an orientation towards } \\
\text { managing efficiency, adaptability, and } \\
\text { flexibility }\end{array}$ & $\begin{array}{l}\text { Development of a philosophy of quality } \\
\text { management on the principles of change } \\
\text { management (change management in an } \\
\text { organisation), recognition of the } \\
\text { flexibility and adaptability of quality } \\
\text { systems as economic and managerial } \\
\text { tools to ensure the effectiveness of } \\
\text { quality management }\end{array}$ \\
\hline $\begin{array}{l}\text { Methodological approach to the } \\
\text { establishment of flexibility and } \\
\text { adaptability of quality } \\
\text { management systems, based on } \\
\text { the allocation of three phases of } \\
\text { their development, depending on } \\
\text { the level of indicators of their } \\
\text { measurement }\end{array}$ & $\begin{array}{l}\text { Adaptability - a characteristic that } \\
\text { determines the transition from a phase } \\
\text { of decline to an increase in the } \\
\text { flexibility of the quality management } \\
\text { system at the enterprise, makes } \\
\text { provision for the transition from the } \\
\text { mechanisms of flexibility of the quality } \\
\text { management system to mechanisms of } \\
\text { adaptability }\end{array}$ & $\begin{array}{l}\text { Allows to consider the possibility of } \\
\text { introducing or applying more flexible } \\
\text { methods of quality management } \\
\text { according to the developed model of } \\
\text { dependence "flexibility - adaptability" } \\
\text { and the development of a quality } \\
\text { management system at the enterprise }\end{array}$ \\
\hline $\begin{array}{l}\text { Mechanisms for the } \\
\text { development of maps of quality } \\
\text { management methods of } \\
\text { business processes of enterprises } \\
\text { as tools for flexibility and } \\
\text { adaptability of quality } \\
\text { management systems }\end{array}$ & $\begin{array}{c}\text { Method maps allow for a flexible } \\
\text { solution of quality problems based on } \\
\text { alternative selection and optimisation } \\
\text { of management decisions in the field } \\
\text { of quality }\end{array}$ & $\begin{array}{l}\text { Criteria for determining methods based } \\
\text { on the implementation time, the waiting } \\
\text { time for the effect, the material and } \\
\text { financial costs of enterprises for the } \\
\text { implementation of certain methods and } \\
\text { the sustainability of the result; } \\
\text { improvement of quality over time }\end{array}$ \\
\hline $\begin{array}{l}\text { Mechanisms for the use of the } \\
\text { enterprise benchmarking system } \\
\text { based on the characteristics of } \\
\text { their quality management } \\
\text { systems, which, in turn, are } \\
\text { based on international and } \\
\text { national quality management } \\
\text { standards }\end{array}$ & $\begin{array}{c}\text { Model for assessing opportunities, } \\
\text { risks, and ways to overcome the risks } \\
\text { of participation of enterprises in } \\
\text { competitions and awards for quality as } \\
\text { elements of benchmarking enterprises } \\
\text { and quality management systems in } \\
\text { them }\end{array}$ & $\begin{array}{l}\text { General requirements for the adaptability } \\
\text { and flexibility of enterprise quality } \\
\text { management systems are developed, } \\
\text { which are advisable to ensure during the } \\
\text { benchmarking process }\end{array}$ \\
\hline $\begin{array}{l}\text { Tools to overcome staff } \\
\text { resistance and obstacles in the } \\
\text { establishment of flexibility, } \\
\text { adaptability, and quality } \\
\text { assurance of business processes } \\
\text { of enterprises }\end{array}$ & $\begin{array}{l}\text { Overcoming obstacles to the } \\
\text { establishment of adaptability and } \\
\text { flexibility of business processes is built } \\
\text { on the principles of teamwork in } \\
\text { product quality assurance systems and } \\
\text { accounting for errors in quality } \\
\text { management }\end{array}$ & $\begin{array}{l}\text { Based on well-known approaches to } \\
\text { teamwork in project management, a } \\
\text { range of tools is added that can be } \\
\text { successfully used in the management of } \\
\text { teamwork for quality management, } \\
\text { principles of teamwork and positioning of } \\
\text { working groups in the management of } \\
\text { quality assurance systems for business } \\
\text { processes are substantiated }\end{array}$ \\
\hline
\end{tabular}


The presented sequences and relationships allow to assess the flexibility and adaptability of quality management of business processes. It is these signs that determine attention to the existing and potential management system tools, which are most appropriate for use in certain managerial circumstances and situations. The first way to ensure quality is the prerogative of the flexibility of the quality management system, it is the response of the quality system to the emergence of certain requirements, which ensures a smooth transition of qualitative changes in products to form a new quality structure. The second way is the task of adaptability of the quality management system, which ensures a fundamental change and revision of quality. The basis of changes is fundamental changes and an increase in the technical level of production and rendering of services.

The second way is more complicated - due to the development and emergence of new consumer requirements, there is often a large gap in their satisfaction. If the quality characteristics of products do not consider the expected future demands, this gap must be filled over time. The filling will lie in changing the composition of product characteristics, the emergence of new qualitative characteristics. The second way is important from the standpoint of the presence of elements of adaptability and flexibility of the quality management system. Methods for assessing the flexibility and adaptability of the quality management system of business processes of an enterprise developed based on research in the theory and practice of business process management are presented in Table 3 . The study of the practice of business process management indicates that it is of great importance for the flexibility of quality management systems that their methods of eliminating inconsistencies can change. Difficulties in the transition from one method to another indicate the low flexibility and adaptability of the quality management system. Transitions between the use of different methods may require certain financial costs and a certain time lag. Based on the generalisation of theory and practice on the management of business processes, the approaches to identifying signs of flexibility of the quality management system of business processes have been improved. To ensure and increase flexibility in accordance with the developed sequence that business processes need to be adapted to new management methods (for this they must be described by adaptability to transformations).

Table 3 Methods for assessing the flexibility and adaptability of the quality management system of business processes

\begin{tabular}{|c|c|}
\hline Development names & Research methods \\
\hline $\begin{array}{c}\text { A set of indicators of the level of adaptability and } \\
\text { flexibility of the enterprise quality management } \\
\text { system }\end{array}$ & $\begin{array}{l}\text { They consider the factors of time and material costs that are } \\
\text { necessary for the implementation of management decisions } \\
\text { aimed at eliminating the identified inconsistencies in the quality } \\
\text { management system at the enterprise. Separately, the time period } \\
\text { for obtaining a positive economic effect from the implemented } \\
\text { management decisions is considered }\end{array}$ \\
\hline $\begin{array}{l}\text { Identification of signs of flexibility of the quality } \\
\text { management system at the enterprise and its } \\
\text { adaptability }\end{array}$ & $\begin{array}{l}\text { The flexibility of the quality management system does not imply } \\
\text { the automatic adaptability of this component of the management } \\
\text { system, which allows it to use a greater gradient of changes than } \\
\text { flexibility (their level), responding to new challenges from the } \\
\text { market, consumers, suppliers, etc., and internal factors of quality } \\
\text { management }\end{array}$ \\
\hline $\begin{array}{l}\text { Methodological approaches to assessing the } \\
\text { importance of enterprise business processes based } \\
\text { on the vertical integration indicator }\end{array}$ & $\begin{array}{l}\text { The indicator is based on a methodological approach based on the } \\
\text { value added to the intermediate and final products of the } \\
\text { enterprise, is used to focus the quality management system on } \\
\text { flexibility and adaptability }\end{array}$ \\
\hline $\begin{array}{l}\text { A model for the determination of the economic } \\
\text { efficiency of quality management systems at an } \\
\text { enterprise based on the ratio of results from its } \\
\text { operation and the costs of its implementation }\end{array}$ & $\begin{array}{c}\text { Considers the difficulties of assessing the quality management } \\
\text { system in connection with the synergistic effect and parallel } \\
\text { management processes at the enterprise }\end{array}$ \\
\hline $\begin{array}{l}\text { Indicators of the flexibility of the quality } \\
\text { management system in the supply logistics of the } \\
\text { enterprise }\end{array}$ & $\begin{array}{l}\text { The proposed indicators are adapted to the quality assurance of } \\
\text { the enterprise's supplies }\end{array}$ \\
\hline $\begin{array}{l}\text { Model for comparative assessment of the } \\
\text { flexibility of quality management systems for } \\
\text { business processes of enterprises }\end{array}$ & $\begin{array}{l}\text { The comparison is recommended to be carried out based on a } \\
\text { fixed description of the requirements for flexibility, adaptability, } \\
\text { and quality of business processes in the pyramid of enterprise } \\
\text { documentation on quality management }\end{array}$ \\
\hline
\end{tabular}


Quality management systems based on flexibility and adaptability should respond as quickly and cost effectively as possible to the emergence of changes in these problems. The response should also correspond to situations of non-compliance of product quality characteristics with requirements on a systematic or systematic basis. Among the numerous definitions of the concept of "product quality", most are formulated in such a way that, directly or indirectly, they make provision for the flexibility and adaptability of the quality management system as its indispensable properties.

For example, the definition of this concept by the European Organisation for Quality Control: "A product is considered to be of good quality if, at minimum costs throughout its life cycle, it maximises the health and happiness of people involved in its design and restoration (reuse), subject to minimum costs energy and other resources and with an acceptable (permissible) impact on the environment and society)". This quite clearly defines the connection between the task and problems of product quality assurance with global and local problems that are important for consumers. To streamline the quality terminology of the International Organisation for Standardisation (ISO), clarification of definitions has been developed, standards of the International Organisation for Standardisation (ISO) 8402:1994 series have been developed, approved, and published. Evolutionarily, this standard, after revision, was introduced into the new series of standards ISO 9000:2000. During the research, the terms and definitions regulated by this standard were considered. The model of the quality management system in the enterprise aims to adapt to their changing environment, each requires the ability to change. The organisation's business process quality management system model recognises that not all systems, processes, and activities can be predetermined; therefore, it must be flexible and easily adaptable in a complex organisation environment.

"Quality management" is understood as the entire scope of problems from international, national (state) management to quality management at the levels of individual enterprises. Management at micro, macro, and meso levels. This study reflects the problem of quality management at the level of the management system of industrial enterprises. Among the many aspects of quality management, which has grown from one of the sections of management into a fairly autonomous system of knowledge, skills and abilities, modern scientific developments, scientific and practical inventions and know-how, a certain feature is highlighted in the operation. This feature helps to adapt quality, the system that controls it in modern enterprises, to the requirements of the internal and external environment. Furthermore, this feature implies special attention to such a general function of any management system as regulation, and to the specific function of the management systems of the most successful enterprises - ensuring organisational changes and enterprise development. For the sake of this study, this feature is called the adaptability and flexibility of the enterprise quality management system. In modern intensive conditions of economic development, quality, as a factor of competition, becomes a decisive factor in the existence of an enterprise and its successful development. Achieving high quality of the company's products, goods and services requires effective and reasonable management actions, influences, and methods. The result of these actions is the development of alternatives, optimisation, adoption, and implementation of management decisions aimed at maintaining and improving the quality of goods and services. The system for making the most optimal decision should be based on proper information and analytical support. Namely: assessment of the environment for decision-making, assessment of quality problems that are solved in quality systems, should be based on the principles of statistics, make provision for the construction of statistical methods of assessment and analysis.

Of significant importance to the flexibility of quality management systems is how their methods of resolving nonconformities can change. The most valuable and costly methods are used to prevent inconsistencies, however, the use of these methods to correct them indicates a lack of flexibility. And the complexity of the transition from one method to another indicates the low adaptability of the quality management system of business processes. It is logical to assume that the transition between the use of different methods may require certain financial costs and a certain time lag. Costs arise because of both structural changes in business processes and changes in their rhythmic flow. The most vital role in this is assigned to the training of personnel in the use of various methods (Romero \& Cortes, 
2014). As evidenced by numerous studies at manufacturing enterprises, this refers to a system of cyclical continuous training and advanced training.

Business process reengineering techniques are actively used to improve efficiency, ensure flexibility and adaptability of the quality management system. The systems that operate both in the enterprise and the newly created ones make provision for elements of change that can be expected and that constitute backup steps to improve quality. Complex systems, especially in Japanese leading corporations, allow to rank among quality indicators, in particular, reducing enterprise costs, increasing labour efficiency, reducing labour intensity, improving other economic results of a manufacturing enterprise. To assess the potential for flexibility, barriers to achieving this characteristic of the system, it is necessary to identify and analyse all the main business processes in the enterprise. As is known, this is ensured by total quality management (TQM) and international quality standards and allows to obtain a list of management objects that can support flexibility and adaptability, and through detailed description, analysis, and in-depth study of business processes, flexibly manage the interrelations of each process with other processes in the enterprise. Identification of ineffective processes, with errors and shortcomings, provides guidelines for the development of directions for eliminating inconsistencies in quality and improving results at the output of the process.

The establishment and use of adaptive quality management systems for business processes contributes to the creation of a flexible and adaptive management system at the enterprise level. Therewith, adaptability means a certain efficiency of adaptation to changes in the external and internal environments. The operational and strategic levels of business processes and their quality management in enterprises are often distinguished. The transition from ensuring the appropriate quality of services and products stipulated by contracts to the selection and implementation of quality methods based on optimal management decisions in the quality management system. The construction of a quality management system and its adaptation at the enterprise to certain business processes are developed based on adaptation, which is carried out in accordance with the quality characteristics (Sanchez et al., 2014).

The study carried out at enterprises and the study of literary scientific sources indicated that, in modern quality management, the most common approaches to determining quality exist based on the cost of ensuring it. Many recommendations were proposed for classifying the costs of ensuring the quality of business processes. A classification was developed in two aspects - the costs of maintaining the specified parameters of product quality and the costs of improving product quality. On this basis, methodological foundations and registers for their analytical and synthetic accounting were proposed, which provide an information base for conducting both operational and subsequent control and analysis by the level of their development. The condition for the implementation of a prompt, broad and detailed economic analysis to control the quality of production processes is the establishment of a high-quality information base of the enterprise. Insufficient attention to this factor narrows the possibilities of control, reduces the level of responsibility of management and personnel of enterprises for the implementation and observance of recommendations and mandatory requirements of quality standards and requirements of technical specifications. Export-oriented enterprises are gradually switching to the use of European regulations as analogues of technical specifications. Practical experience allowed to formulate recommendations for improving profile quality indicators in modern business, grouping the types of products of an enterprise with subsequent detailing of the necessary data by quality categories. Adaptation in accordance with the goals of quality management of statistical and financial reporting forms (including for indicators of the main categories of product quality) can expand the field of opportunities for managing costs to ensure its quality (Hameed et al., 2021).

Studies of the establishment and distribution of specific management functions in the enterprise management system indicated that management activities are largely focused on the active use of the regulation function. The main motive for attention to this function is the impossibility of foreseeing all the features of the control object at the planning stage. Attention to the development and application of the personnel component of the enterprise management system enhances the powerful potential 
for improving product quality and the competitiveness of the enterprise as a whole (Azam \& Qureshi, 2021).

\section{Conclusions}

At present, statistical methods for assessing the quality management system, which are sufficiently supported by mathematical methods and models, are used. Statistical service quality management requires the selection and justification of methods for assessing quality, a set of indicators, methods of factor analysis of visible hidden and indirect signs, validity of quality assessment, statistical methods of analysis. To the greatest extent, the modern principles of TQM to support the adoption of scientifically based decisions on quality management are met by statistical methods of data processing and analysis. The introduction of the principles of total (general, integrated) quality management (TQM) has become widespread in quality management. As a kind of theory of modern management, TQM assumes the presence of signs of flexibility and adaptability of the quality management system of business processes. In particular, TQM makes provision for customer orientation and reorientation, leadership in flexible and adaptive changes, employee involvement in the change process, a process approach to change, a systematic approach to ensuring management flexibility; constant review of options for improvements and improvements, consideration of alternative management decisions and their optimisation and adoption based on facts and statistics; mutually beneficial relationship regarding changes with partners and suppliers. An important principle of a modern quality management system at an enterprise is the focus of management on key processes (business processes): management responsibility; resource management; output; measurement, analysis and improvement.

Based on the assessment of the dynamics of certification of quality management systems in accordance with international standards, the relationship of these processes with the number and profitability of enterprises by sector of the economy was determined. The analysed data on the certification of enterprises in accordance with international quality standards give grounds to talk about the adaptation of standards to certain types of activities and their business processes and the existence of tendencies towards increasing requirements for their flexibility. The results of such a comparison indicate a fairly high concentration of interests in international certification in several industries, which are distinguished by high earning power, profitability, and investments, mainly, these are enterprises from 4-5 most dynamic sectors of the economy focused on close cooperation with foreign partners.

\section{References}

1. Azam, M., \& Qureshi, J. A. (2021). Building employer brand image for accumulating intellectual capital: Exploring employees' perspective in higher educational institutes. Estudios De Economia Aplicada, 39(2), 1-15.

2. Chen, C. -K., Shih, Y. -P., \& Tsai, C. -H. (2010). Examining the quality management maturity level in different enterprises size in terms of the self-assessment viewpoint. Journal of Quality, 17(1), 1-20.

3. Chen, H. -G., Fu, Q., Zhang, Y. -H., \& Ao, C. -L. (2009). Construction enterprise quality management system effectiveness of impact analysis. In: Proceedings - International Conference on Management and Service Science, MASS. https://ieeexplore.ieee.org/document/5302861. [Accessed January 22, 2021].

4. Feng, L., Luo, M., Peng, B., \& Ren, J. (2007). Study on integrated quality management system for the life cycle of virtual enterprise. In: 2007 International Conference on Wireless Communications, Networking and Mobile Computing, WiCOM. https://ieeexplore.ieee.org/document/4341019. [Accessed January 26, 2021].

5. Hameed, K., Arshed, N., Yazdani, N., \& Munir, M. (2021). On globalization and business competitiveness: A panel data country classification. Estudios De Economia Aplicada, 39(2), 1-27. 
6. Jia, H., \& Jia, Y. (2014). Application of improved entropy, catastrophe progression and set pair analysis method in extracting fuzzy rules of enterprise quality management system operation effectiveness. Journal of Chemical and Pharmaceutical Research, 6(6), 348-53.

7. Kymal, C. (2006). Enterprise quality management evolves. Quality, 45(11), 36-9.

8. Liping, S., Qiang, L., \& Xingwei, Z. (2014). Application of method sets in evaluating enterprise quality management maturity. An Indian Journal, 10(11), 5690-9.

9. Liu, C. -Y., \& Sun, Y. -F. (2009). Modeling process integrated quality management system in manufacturing enterprises. In: 2009 International Conference on Future Information Technology and Management Engineering, FITME. https://ieeexplore.ieee.org/document/5380926. [Accessed January 29, 2021].

10. Martins, Â., Pinto Ferreira, J. J., \& Mendonça, J. M. (2001). Quality certification in the virtual enterprise: An objective tool for supply chain management and customer satisfaction. Advances in Information and Communication Technology, 56, 479-86.

11. Martins, A., Pinto Ferreira, J. J., \& Mendonça, J. M. (2004). Quality management and certification in the virtual enterprise. International Journal of Computer Integrated Manufacturing, 17(3), 212-23.

12. Peng, W., Lu, R., \& Wang, C. (2008). An enterprise-wide project quality management system in manufacturing industry. International Federation for Information Processing, 255, 1335-46.

13. Ren, S. Z., \& He, G. J. (2013). Study on the quality management of construction enterprise. Advanced Materials Research, 639-640(1), 1281-4.

14. Romero, F. T., \& Cortes, E. A. (2014). Association between business characteristics and intellectual capital disclosure: a study of companies in the ibex 35. Estudios de Economia Aplicada, 32(1), 37198.

15. Sanchez, A. C. Flores, M. A. C., \& Alcantara, J. R. M. (2014). Social accounting matrices and applied general equilibrium models developed in Spain at regional level. Estudios de Economia Aplicada, 32(1), 427-54.

16. Schmeleva, A. N. (2017). Evaluation and improvement of the operating efficiency of enterprise quality management system (QMS): Conceptual bases. Quality - Access to Success, 18(160), 100-7.

17. Su, H., Ma, X., \& Ma, J. (2010). Research on production-oriented virtual enterprise quality information management. In: Proceedings - 2010 International Conference on Service Science, ICSS. https://ieeexplore.ieee.org/abstract/document/5494340?section=abstract. [Accessed February 2, 2021].

18. Wang, W., \& Srivastava, G. (2020). Enterprise human resource quality management model based on grey relational analysis. International Journal of Performability Engineering, 16(3), 419-29.

19. Wang, X.-C. (2018). Error identification and analysis of enterprise quality management based on ISO9001 quality management standard and FMEA method. Journal of Interdisciplinary Mathematics, 21(5), 1291-6.

20. Xiaofen, T. (2013). Investigation on quality management maturity of Shanghai enterprises. TQM Journal, 25(4), 417-30.

21. You, J., \& Zhu, L. (2009). Study on government supervision game mechanism for enterprises establish quality management system. In: Proceedings - International Conference on Management and Service Science, MASS. https://ieeexplore.ieee.org/document/5301812. [Accessed February 5, 2021].

22. Zhang, Z.-L., \& Dai, F.-S. (2013). Application of quality management maturity assessment system in small and medium-sized enterprises. In: International Asia Conference on Industrial Engineering and Management Innovation: Core Areas of Industrial Engineering, IEMI. https://www.researchgate.net/publication/283598479_Application_of_Quality_Management_M aturity_Assessment_System_in_Small_and_Medium-Sized_Enterprises. [Accessed February 10, 2021].

23. Zhilkina, A.N. (2008). Enterprise financial management quality control. In: 2008 International Conference on Management Science and Engineering 15th Annual Conference Proceedings, ICMSE. https://www.semanticscholar.org/paper/Enterprise-financial-management-quality-controlAnna/21a0e5195909c43b99267b68e79cac96294e2482. [Accessed February 18, 2021]. 